\title{
The Originality of English Newspaper Titles
}

\author{
Guineng Mei \\ Foreign Languages College, Zhejiang Gongshang University, China
}

\begin{abstract}
This paper argues that English newspaper titles must be original to apply to a growing number of readers. Here the most important approaches to write original English newspaper titles are introduced to illustrate that how charming and appealing the English language in newspaper titles will be if it is used creatively.
\end{abstract}

Index Terms —originality, titles, English newspaper, flexibility, borrowing words, buzzwords

\section{INTRODUCTION}

Titles of a newspaper are the most important part of a newspaper because people depends on whether the newspaper is worth reading or not by looking at the titles (Fanjian Hua, 2008) and people only read those that appeal to them. The success of a newspaper depends largely on the originality of the titles that must be concise, attractive, imaginative, impressive and creative. If titles of newspaper English are very common even boring, perhaps nobody would like to read the newspaper. Therefore the English language of the titles of a newspaper of English plays the most vital part in the newspaper. Here I dwell on how titles of newspaper English are original.

\section{DISCUSSION AND ANALYSIS}

The originality of titles of newspaper English goes as follows.

\section{A. Coinage}

Coinage refers to the inventing of a word or phrase. Sometimes some words or phrases can be coined in order to make the titles give the impression of being concise, vivid and imaginative. For example.

1. Three wants and three want-nots (Chen Yuming, 2013)

The title here is the one in China Daily by Chen Yuming on March 14, 2013 that emphasizes our President Xi's views on China's foreign policy that seeks peace, development and cooperation instead of conflict, poverty and confrontation. Here the coinage of the words of the title avoids the lengthy to express the specific foreign policy and impresses people very much.

2. Biden: Obama gave me 'every s- -t job in the world' (S.A. Miller, 2014)

Here is the title by S.A. Miller in New York Post on February 27, 2014 that Vice President Joe Biden complained that he was given every s- -t job but still wasn't fully trusted by President Obama. The title reveals that the revelations about Biden's tortured relationship with Obama. Here the coinage of the word s- -t means the vice president was not satisfied with the president since the latter gave him s- -t job (every unsavory job).

3. The do-it-yourself pension plan - Money Clip (Today Reuters, 2013)

Workers are offered pensions by fewer companies but they still need income after retirement. Here the do-it-yourself pension plan is the four ways to turn your portfolio into a pension plan.

\section{B. Abbreviation}

The initials of the words are used to arouse the curiosity of readers to guess the meaning of the abbreviation. On the other hand, abbreviation can avoid the lengthy phrase. For example.

1. Dzhokhar Tsarnaev charged with using WMD (Sari Horwitz, Jenna Johnson and Kathy Lally, 2013)

The Washington Post Published the title Dzhokhar Tsarnaev charged with using WMD to show that the suspect in the Boston Marathon bombings was charged with using a "weapon of mass destruction".

2. NYC proposing raising age for tobacco purchase (ASSOCIATED PRES, 2013)

Here the abbreviation NYC stands for New York City Council.

3. Beijing planning new airport in $\mathbf{S}$ suburbs (Xinhua, 2013)

Here $\mathbf{S}$ suburbs represents southern suburbs.

4. COFCO sows seeds of further overseas growth (Ding Qingfen and Bao Chang, 2012)

COFCO here stands for China National Cereals, Oils and Foodstuffs Corp.

5. China adds more QFII A-share accounts (Xinhua, 2014)

QFII is the abbreviation of Qualified Foreign Institutional Investors.

C. The Flexibility of Parts of Speech of the Words

Household words are chosen to appear in the titles of newspaper English in order to be easily understood by readers, 
so these words are used very flexibly to attract people's attention. For example.

\section{Adjectives used as verbs}

1.1 China's January inflation slows to 2\% (BEIJING, 2013)

The National Bureau of Statistics (NBS) stated that China's inflation in January decreased to $2 \%$.

1.2 Vancouver housing price slide prompts owners to pull homes off market (Garry Marr, 2012)

The prices of homes fall down. And the owners sell the houses at lower prices.

1.3 Travel peak nears end (chinadaily.com.cn, 2013)

Travel peak is about to end.

1.4 Avian flu quiets song in bird market (Shan Juan and He Na in Beijing, and Wang Hongyi in Shanghai, 2013)

In bird market live fowl is banned to sell because of bird flu.

1.5 China's World Cup hopes dimmed after home loss to Iraq (SHENZHEN, 2011)

Here dimmed refers to the fact that China's qualifying hopes for the 2014 Brazil World Cup became remote after a key home 1-0 loss to Iraq on Tuesday.

1.6 Carnival cools nerves? (Amy Tennery, 2014)

As the festivities begin, there's hope for some rest in the Venezuelan unrest.

1.7 China's vehicles exports topped the one-million mark for the first time in 2012 (LI FANGFANG, 2013)

Car exports from China surpassed one million for the first time in 2012.

\section{Nouns as verbs.}

2.1 Auto maker eyes Europe. (South America)

Auto maker looks well to Europe.

2 .2 Could Earth's Population Peak in 2050? (Henry Grabar, 2013)

Could the population on the earth become the largest in 2050 ?

2.3 E. coli-Produced Diesel Could Power Cars (Jason Koebler, 2013)

Coli-produced diesel could provide power for cars.

2.4 Beauty queen will charm the masses - of snakes (Molly Hennessy-Fiske, 2013)

Here Los Angeles Times published the title to show that the most beautiful woman will attract the audiences who watch the rattlesnakes show.

2.5 Snooty Hamptons club rage over proposed new members (New york Post, 2013)

The members of Snooty Hamptons club are furious over the new members proposed.

2.6 China to cap pollutant emissions in 6 industries (Xinhua, 2013)

Here cap means to limit the top of pollutant emissions.

2.7 New leaders target environment (He Na, Wu Wencong and Tang Yue 2013)

New leaders set the target to protect environment.

2.8 African competition heats up (Li Jiabao, 2013)

Here Africa competes not only with western countries but also with their fellow Chinese.

2.9Latest government curbs hammer property stocks

Latest government curbs on real estate make the stock markets fall sharply.

2.10 FDI increase ends 8-month run of declines (Li Jiabao, 2013)

FDI increase finishes 8-month run of declines

2.11 Premier maps out tasks for cabinet

The Premier makes out the blueprints for the tasks for the cabinet.

2.12 Electric car consortium inks bus deal with Poland (Li Fangfang, 2013)

Chinese electric car consortium has signed agreements with Poland to help develop an electric bus network.

2.13 China's banks finance more small companies (Xinhua, 2013)

Banks in China gave more loans to small and micro-sized enterprises.

2.14 Shale gas to spark equipment boom (DU JUAN, 2013)

The development of shale gas can bring opportunities for business to the related industry to manufacture equipment.

2.15 US backs Syrian opposition move to open talks with Assad.

US supports Syrian opposition move to open talks with Assad.

2.16 CSRC to ease regulations for QDII applicants (Wu Yiyao, 2013)

The CSRC lowers the requirements for applicants for QDII.

2.17 Children toy with new forms of leisure (Shen Jingting, Chen Limin and Gao Yuan, 2013)

Nowadays school children use an iPad or a computer or a mobile phone to play net games as a new form of leisure instead of traditional toys.

2.18 Todd English snapped partying in hot tub with topless babes (Stephanie Smith, 2014)

An English man hugged three half-naked women at a hotel party, which is pictured.

\section{Adverbs as verbs}

3.1 China's farm produces prices down (Xinhua, 2013)

Farm produce prices in China have gone down. 
3.2 Japan ups stakes in islands dispute (ZHOU WA, 2013)

Japan elevates the territorial dispute with China on Diaoyu Islands.

3.3 China's January exports up 25\%, imports up 28.8\% (Xinhua, 2013)

China's foreign trade in January increases by $25 \%$ in exports and $28.8 \%$ in imports.

3.4 CNOOC's 2012 profits down $9.3 \%$ (Xinhua, 2013)

China's largest offshore oil producer, the China National Offshore Oil Corporation Limited decreased by 9.3 percent.

3.5 Student who outed Belle Knox has \$1K-a-month porn habit (Jeane MacIntosh, 2014)

The student who triumphed over Belle Knox has \$1K-a-month porn habit.

4. Adjectives as nouns

4.1 Iraq allowed to play friendlies at home, says FIFA (ZURICH Agencies, 2013)

Iraq is to be permitted to play friendly matches at home.

4.2 Rich find spirit of generous giving

It is very generous of China's rich people to donate large sum of money to the charity.

4.3 Chronically ill facing high drugs costs under U.S. health law (David Morgan, 2014)

The chronically ill patients are facing high drugs under U.S. health law.

4.3 Shanghai car plate auction hits new highs (SHI YINGYING, 2013)

The cost of a car license plate has reached highest.

4.4 Median sale price of homes in Washington, D.C., hits record high (Kathy Orton, 2013)

Here Washington Post published the title to show that the median price of a home in Washington, D.C. reached highest in history.

5. Verbs as adjectives

Crackdown on pretend Kobe beef (Wang Zhenghua, 2013)

The law is to strictly ban the imports of beef produced in areas affected by mad cow disease.

6. Adjectives used as adverbs

China's farm produce prices rise slower (Xinhua, 2013)

Farm produce prices rose more slowly in China.

7. Nouns used as attributives

7.1 Paid sick day protection gains steam across the U.S. (Claire Zillman, 2014)

To protect workers from going to work sick, people claim the workers get paid on sick days when they ask for leave.

7.2 U.S. expands access to healthy foods for low-income women and children (Katie Mcdonough, 2014)

The United States of America expands access to healthy foods for women and children who have low incomes.

7.3 A nuclear weapons strategy that's stuck in the past (Rachel Maddow, 2014)

A strategy for nuclear weapons was stuck in the past.

7.4 Basquiat sale goes on despite 'fakes' suit (Mara Siegler, 2014)

In spite of claiming of fakes, Jean-Michel Basquiat sale continues without any huge obstacles.

\section{Omission}

To emphasize the vitals and save time and space, some minors can be omitted. For example.

1. The omission of modifying words

1.1 Women-only adverts are illegal, Muslim schools told (Ruth Gledhill Religion Correspondent of The Times, 2014)

Here women-only adverts means adverts that the schools want only female staff.

1.2 Queens teacher's cellphone code 'for sex’ with student (Jamie Schram, 2013)

Here Queens teacher refers to Teacher Daniel Reilly yesterday outside Queens court.

2. Omission of prepositions

1.1 Top Chefs Talk Healthy Eating (U.S. News Staff, 2013)

Top chefs Mike Isabella, Spike Mendelsohn and Art Smith argue over important health and food issues

3. Omission of articles

3.1 Making government more efficient and innovative will be key target

Making government more efficient and innovative will be the key target.

3.2 Woman and museum both fight for stolen Renoir found at flea market (Iran shapira, 2013)

The woman and the museum both fight for stolen Renoir found at the flea market.

3.3 No surprise if North Korea fights missile

It is no surprise if North Korea fights a nuclear missile war

4. Omission of linking verbs

4.1 Rehtaeh Parsons Suicide: Justice Minister Revisiting Alleged Rape Case

Rehtaeh Parsons Suicide: Justice Minister Is Revisiting Alleged Rape Case

4.2 Chinese investors confident in stock market

Chinese investors are confident in stock market

4.3 Air pollution 'more frightening than SARS virus' (Li Wenfang, 2013) 
Air pollution is more frightening than SARS because no one can escape it.

4.4 Li winning world recognition (Sun Xiaochen, 2013)

$\mathrm{Li}$ has been winning world recognition

4.5 Train tickets in short supply (Wang Xiaodong, 2013)

Train tickets are in short supply.

5. Omission of nouns

5.118 suffer food poisoning in Central China (Xinhua, 2013)

Eighteen people suffered food poisoning in Central China.

5.2 Man's lifelong affection for his wife moves millions on the Web

Man's lifelong affection for his wife moves millions of people.

5.3 20,000 support Mont. teacher fired for pregnancy (John S. Adams, 2014)

Catholic school fired unmarried woman after Helena diocese received anonymous letter. Over 20,000 people throughout the USA protested the decision to dismiss a middle school teacher who is unmarried but pregnant. They supported and took pity on her.

6. Omission of subjects, predicates and prepositions

6.1 Opportunities, not threats (Wu Jiao, Zhao Shengnan and Qin Zhongwei, 2013)

China's development creates opportunities instead of threats, President Xi Jinping said on Saturday.

6.2 Increased salary expectations (Gao Yuan, 2013)

Job-hoppers can expect income increase of 15 to $20 \%$

6.3 Enough already! More snow to sock NYC (Natalie O’neill, 2014)

There's snow end to this weather! March will roar into New York and drop up to 10 inches of snow starting Sunday night and into Monday.

From the thirst sentence we can see that enough already here means there has been already enough snow or it has already snowed enough now.

6.4 Today Crimea, tomorrow... us? (William Cook, 2014)

The title here means If today Russia invades Crimea, will it invade us tomorrow?

\section{E. Rhetoric}

Rhetoric is used in the titles of newspaper English to give the impression of vividness and imagination. Pun, metaphor, metonymy, and especially personification are widely used in titles of newspaper English. For example.

1. Lone female student leaves 29 broken hearts (Chinadaily, 2013)

The only female student who majors in mining at a university in Wuhan has applied for a transfer, and all the other 29 male classmates asked her to stay. Here the word leaves is a pun meaning that the lone female student says good-bye to her classmates and her departure makes her 29 classmates heart-broken. (pun)

2. Islands are root of tension (ZHANG YUNBI, 2013)

The Diaoyu Islands are the origin of tension in the relationship between China and Japan. Here the origin of the tension is compared to root. (metaphor)

3. Who rocked the best CPAC speech: Christie, Cruz, Ryan or Trump? (Robin Abcarian, 2014)

At the Annual Conservative Political Action Conference in National Harbor, Md., on Thursday, New Jersey Gov. Chris Christie came to woo conservative activists on the first day of the three-day event. Some opened their speeches with jokes; others got right down to business. Here rocked is used to mean "delivered the speech as good as possible as they performed a rockn'd roll"' (metaphor)

4 potential killers lurk as bull market hits 5 (Adam Shell, 2014)

Wall Street bull is only sixth bull in post-war era to reach its fifth birthday. Despite skeptics saying it couldn't last, bull's $177 \%$ gain ranks fifth all-time. Investors are on the lookout for warning flags that could spell an end to the rally by 4 potential risks. (metaphor)

4 The inside story of how the White House learned to love the minimum wage (Zachary Goldfarb, 2014)

President Obama now favors a $\$ 10.10$ an hour minimum wage, but his advisers initially worried about going that high. Here the White House is used to refer to the US president. (metonymy)

5. Health-care law uncertainty grips Old Town Alexandria cafe — and other small businesses (J.D. Harrison, 2013)

The uncertainty of health-care law limits the development and prosperity of the old town Alexandria café and other small business. The Washington Post published the title to use grip to personify the result by the uncertainty of health-care law. (personification)

6. Bird flu fears see stocks hit lowest level in 2013 (Xie Yu in Shanghai, 2013)

Because of the scare of the bird flu, Chinese stocks reached the lowest points in 2013. (personification)

7. US job figures set alarm bells ringing (personification)

8. Ukraine kicks up its heels in China (Chen Nan, 2013)

Ukrainian musicians, dancers and artists will show all kinds of performances to Chinese audiences to celebrate the 20th anniversary of Sino-Ukrainian diplomatic relations. (personification)

9. Investment breathes life into developing economies (Cecily Liu, 2013) 
Those farmers (in Tanzania) couldn't afford any mechanism in the past because western equipment was too expensive but they now buy Chinese tractors. (personification)

10. Brush captures enduring love (Xu Junqian in Shanghai, 2013)

The old retired military man who is 91 shows his 18 hand-painted albums of drawings of his wife in the past four years to the audiences to express his warm and sincere love to her. (personification)

11. Beijing blanketed by spring snow

Beijing was covered with heavy white spring snow. (personification)

12. New securities regulator installed amid haze and hope (Xinhua, 2013) New securities regulator brings both hope and disappointment to the investors. (personification)

13. Malaria Climbs Mountains as the Climate Warms (By Bryan Walsh, 2014)

Climate change will expand the range of mosquitoes that transmit malaria. (personification)

14. The world's busiest deceased leader (Nick Miroff, 2014)

Venezuela president Hugo Chávez died a year ago. Now the people are busiest with activities to commemorate the anniversary of his death. (personification)

15. Hotter than Ibiza: Sun-kissed Britain set to enjoy a warm weekend as spring arrives with a blaze of clour (Kieran Corcoran, 2014)

Areas in southern England set for warmest temperatures this year - with 18C predicted for London. (personification)

16. Smart pedestrian crossings for London in pioneering new scheme (Matthew Beard, Transport Editor of London Evening Standard, 2014)

Traffic lights will be re-phased to give priority to pedestrians at busy junctions and enable crowds to clear to avoid people spilling onto the street. (personification)

17. Drivers hit as flood shuts road (Catriona Stewart,Columnist/reporter, 2014)

DRIVERS were hit by early morning delays after flooding closed a road in the north of Glasgow. (personification)

\section{F. Borrowing Words}

Words of foreign language have come into the English language. The United States of America is a melting pot, so is the English language. Foreign cultures have to some degree melted into America with the further communications with countries all over the world. Therefore the English language is getting richer and richer, more and more energetic. For example.

1. Judo ( London, 2012)

Judo is a sport in which two people fight with hands and try to throw each other to the ground. It is originated in Japan and has become a popular sport that can be contested in Olympic game.

2. Shrine offers sanctuary to Abe's politics as PM kowtows to right-wingers (Xinhua, 2014)

The People's Daily, the flagship newspaper of the Communist Party of China, on Saturday carried a commentary accusing Japanese Prime Minister Shinzo Abe of using the Yasukuni Shrine as a spiritual sanctuary for his right-wing politics.

3. Gaokao gets accepted by overseas universities (Jin Zhu and Li Xiang, 2014)

Gaokao is the national college entrance exam in China. If a middle school student wants to go to college or university, he or she has to pass the exam. And now more and more overseas universities accept the exam's scores.

4. Zhangjiagang recruits volunteers as chengguan (chinadaily, 2014)

Zhangjiagang Urban Management Bureau is recruiting volunteers to be urban management officers in the city in Jiangsu province and will found the urban management volunteer association to call on citizens to join in urban management work to build a better home.

5. Yunnan groups participate in Singapore River Hongbao gala (Guo Anfei and Li Yingqing, 2014)

Hongbao is a Chinese Spring Festival tradition that a piece of red paper wrapped with money in it as a gift.

6. Honda names first foreigner, female to top management (Agencies, 2014)

Honda is famous Japan's motor brand. The cars produced in Motor Company have been sold well all over the world. Now the company appoints the first female foreigner to be a member of the top management.

\section{G. Buzzwords}

With the growing popularity of the internet, people tend to use the words that frequently appear in the net. This kind of words is very common and popular but sometimes they are inlaid with new meanings. For example

1. Woman gets an IOU as a wedding gift (Hou Liqiang, 2014)

A woman referred to as Xiao Yu in Hangzhou, Zhejiang province, recently received a red envelope containing an IOU note from one of her five university roommates.

Here IOU means I Owe You. The word is used to intensify the meaning that the man is very grateful for the love the woman has offered him.

2. Hot girls at Geneva Motor Show 2014 (Hao Yan, 2014)

Here the hot of hot girls perhaps comes from hot topics. But the word hot here has a new meaning that is to describe the show girl who is most beautiful and fashionable.

3. Beijing's Credibility Deficit (The Wall Street Journal, 2014) 
In modern society money is everything, so people like to talk about thing related to money and some words connected with money have become more widely used. Deficit in the past was only used to refer to the amount of money that is too small or smaller than something else. China is targeting growth of about 7.5\% in 2014, unchanged from last year as the government tempers expectations for an economy transitioning to a more sustainable model. Here Beijing's Credibility Deficit means whether the targeting growth of $7.5 \%$ can be achieved or not is still doubted.

4. Belle Knox: How the porn star student from Duke University became bigger than Justin Bieber (Jenn Selby, Author Biography, 2014)

Here bigger is not used to refer to somebody whose composition is bigger than others but to mean that the porn star student is more successful and well-known and more searched for and clicked in the internet.

\section{CONCLUSION}

Titles of English newspapers play an extremely important role in sales and popularity of the newspaper. If the newspaper is to be the best and the most competitive seller, its titles must be original to be popular with people of all walks of life whether they be female or male, young or old, black or white. How to use the English language skillfully and appropriately in the titles of the newspaper to appeal to readers is a kind of art, the mastery of which will help contribute greatly to the success of the newspaper.

\section{REFERENCES}

[1] Fanjian Hua. (2008). Course of Newspaper English. Suzhou: Suzhou University Press.

[2] Zhangjian. (2007). English in News Publications. Shanghai: Shanghai Foreign Language Education Press.

[3] Chen Yuming. (2013). China Daily. Retrieved March $15, \quad 2013$ from http://www.china.org.cn/opinion/2013-03/14/content_28237105.htm.

[4] S. AMille. (2014). The Washington Post. Retrieved February 29, 2014 from http://nypost.com/2014/02/27/biden-obama-gave-me-every-s-t-job-in-the-world/.

[5] Jerry Markon, Sari Horwitz and Jenna Johnson. (2013). The Washington Post. Retrieved April 25 , 2013 from http://www.washingtonpost.com/national/alleged-bombers-aunt-tamerlan-tsarnaev-was-religious-but-not-radical/2013/04/22/ca 8f3214-ab5c-11e2-a198-99893f10d6dd_story.html.

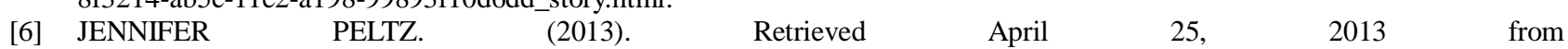

$\begin{array}{llllllll}\text { http://news.yahoo.com/nyc-proposes-raising-age-cigarette-purchases-152353491.html. } & & \\ \text { [7] Xinhua. } & \text { (2013). } & \text { China } & \text { Daily. } & \text { Retrieved } & \text { April } & 23, & 2013\end{array}$ http://www.chinadaily.com.cn/china/2013-03/19/content_16321259.htm.

[8] Ding Qingfen and Bao Chang. (2012). $\quad$ Retrieved $\quad$ March $5, \quad 2013$ from http://www.chinadaily.com.cn/cndy/2012-11/15/content_15930048.htm.

[9] Xinhua. (2014). Retrieved February 5, 2014 from http://www.chinadaily.com.cn/business/2014-01/10/content_17229555.htm.

[10] Xinhua. (2013). Retrieved March 6, 1013 from http://www.chinadaily.com.cn/business/2013-02/08/content_16216513.htm.

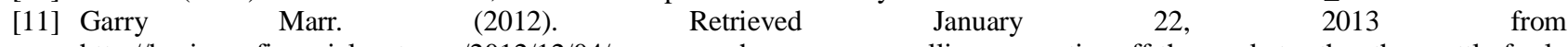
http://business.financialpost.com/2012/12/04/vancouver-homeowners-pulling-properties-off-the-market-rather-than-settle-for-1 ower-prices/.

[12] Chinadaily.com.cn. (2013). Retrieved Jun http://www.chinadaily.com.cn/china/2013-02/25/content_16255090.htm. 8, from

[13] Shan Juan and $\mathrm{He} \mathrm{Na}$ in Beijing, Wang Hongyi in Shanghai. (2013). Retrieved January 25, 2013 from http://english.peopledaily.com.cn/90882/8198230.html.

[14] Xinhua. (2011). Retrieved September 21, 2013 from http://www.chinadaily.com.cn/sports/2011-10/12/content_13875650.htm.

[15] Li Fangfang. (2013). Retrieved October 8, 2013 from http://usa.chinadaily.com.cn/business/2013-01/22/content_16150789.htm.

$\begin{array}{llllll}\text { [16] Henry (2014). } & \text { Retrieved } & \text { May, } & 5 & 2013\end{array}$ http://www.theatlanticcities.com/jobs-and-economy/2013/04/could-earths-population-peak-2050/5208/.

$\begin{array}{lllllll}\text { [17] Jason } & \text { Koebler. } & \text { (2013). } & \text { Retrieved } & \text { June } & \text { 26, } & 2013\end{array}$ http://www.usnews.com/news/articles/2013/04/22/e-coli-produced-diesel-could-one-day-power-cars.

[18] English.news.cn. (2013). Retrieved July 6, 2013 from http://news.xinhuanet.com/english/china/2013-03/06/c_132213734.htm.

[19] $\mathrm{He} \mathrm{Na}$, Wu Wencong and Tang Yue. (2013). Retrieved July 5, 2013 from http://www.chinadaily.com.cn/bizchina/greenchina/2013-03/07/content_16287722.htm.

[20] Li Jiabao. (2013). December 28, 2013 from http://www.chinadaily.com.cn/cndy/2013-03/05/content_16276281.htm.

[21] WU YIYAO. (2013). Retrieved July 5, 2013 from http://www.chinadaily.com.cn/china/2013-03/05/content_16275615.htm.

[22] Jerry Markon, Sari Horwitz and Jenna Johnson (2013). Retrieved July 25, 2013 from http://www.washingtonpost.com/national/alleged-bombers-aunt-tamerlan-tsarnaevwas-religious-but-not-radical/2013/04/22/ca8 f3214-ab5c-11e2-a198-99893f10d6dd_story.html.

[23] Stephanie Smith. (2014). $\quad$ Retrieved $\quad$ March $\quad 8, \quad$ from http://pagesix.com/2014/03/07/todd-english-snapped-partying-in-hot-tub-with-topless-babes/?_ga=1.259195842.972958011.13 93656778.

[24] Jeane $\quad$ MacIntosh
http://nypost.com/2014/03/07/student-who-outed-duke-porn-star-spends-1k-a-month-on-porn/. http://nypost.com/2014/03/07/student-who-outed-duke-porn-star-spends-1k-a-month-on-porn/.

[25] Agencies/Chinadaily. (2013). Retrieved
http://www.chinadaily.com.cn/world/2013-02/06/content_16206113.htm.

[26] Shen Jingting, Chen Limin and Gao Yuan. (2013). Retrieved February 5, 2013 from 
http://usa.chinadaily.com.cn/epaper/2013-01/28/content_16180457.htm.

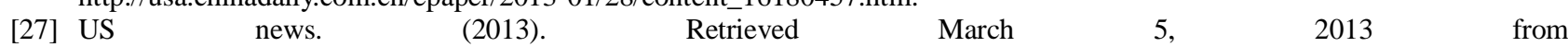
http://health.usnews.com/health-news/articles/2013/04/05/video-top-chefs-talk-healthy-eating.

[28] Jamie Schram. (2013). $\quad$ Retrieved $\quad$ May $\quad 8, \quad 2013$ from http://nypost.com/2013/04/10/queens-teachers-cellphone-code-for-sex-with-student/.

[29] Ruth Gledhill Religion Correspondent. (2014). March 9, 2014 from http://www.thetimes.co.uk/tto/faith/article4025660.ece.

[30] Mara Siegler. (2014). Retrieved March 9, 2014 from http://pagesix.com/2014/03/06/basquiat-sale-goes-on-despite-fakes-suit/.

[31] Xinhua. (2014). Retrieved February 5, 2014 from http://www.chinadaily.com.cn/business/2014-01/10/content_17229555.htm.

[32] William Cook (2014). The Spectator. Retrieved March 5, 2014 from http://www.spectator.co.uk/features/9153391/estonias-angst/.

[33] Bryan Walsh. (2014). Retrieved March 8, 2014 from http://time.com/14553/climate-change-expand-malaria/.

[34] Robin Abcarian (2014). $\quad$ Retrieved $\quad$ March $48, ~ 1014$ from http://www.latimes.com/local/abcarian/la-me-ra-who-rocked-the-best-cpac-speechchristie-rubio-ryan-or-trump-20140306,0,235 7885.story\#ixzz2vGmGtPzc.

[35] Nick Miroff. $\quad$ (2014). $\quad$ Retrieved $\quad$ March $\quad 8, \quad 2014$ from http://www.washingtonpost.com/world/the_americas/divided-venezuela-remembers-hugo-chavez/2014/03/05/5bd23426-a4ac-1 1e3-b865-38b254d92063_story.html?hpid=z1.

[36] Zachary $\quad$ Goldfarb. $\quad$ (2014). $\quad$ Retrieved $\quad$ March $\quad 8, \quad 2014 \quad$ from http://www.washingtonpost.com/blogs/wonkblog/wp/2014/03/06/the-inside-story-of-how-the-white-house-learned-to-love-theminimum-wage/.

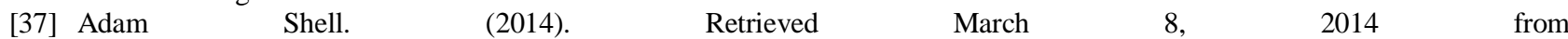

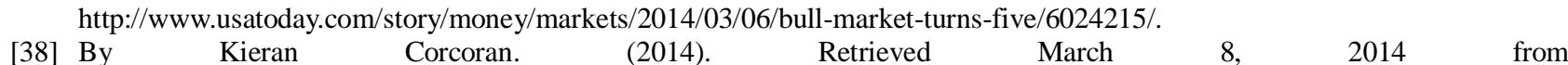
http://www.dailymail.co.uk/news/article-2575599/First-taste-spring-English-strawberries-hitting-shelves-clear-skies-Britain-ma ke-hotter-Ibiza.html\#ixzz2vKKZJjMl.

$\begin{array}{lllllll}\text { [39] Matthew } & \text { Beard. } & \text { (2014). } & \text { Retrieved } & \text { March } & \text { 8, } & 2014\end{array}$ http://www.standard.co.uk/news/transport/smart-pedestrian-crossings-for-london-in-pioneering-new-scheme-9175741.html.

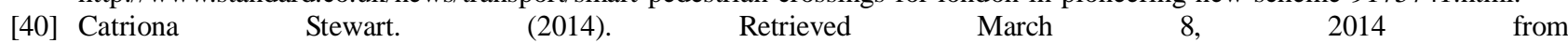
http://www.eveningtimes.co.uk/news/u/drivers-hit-as-flood-shuts-road.1394192696.

[41] London. (2012). Retrieved July 5, 2012 from http://www.chinadaily.com.cn/2012olympics/2012-05/16/content_15306170.htm.

[42] Jin Zhu in Beijing and Li Xiang in Paris (2014). Retrieved March 8, 2014 from http://www.chinadaily.com.cn/cndy/2014-02/24/content_17300136.htm.

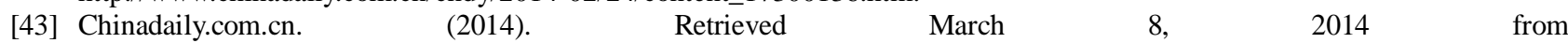
http://www.chinadaily.com.cn/m/jiangsu/zhangjiagang/2014-02/27/content_17311227.htm.

[44] Guo Anfei and Li Yingqing. (2014). Retrieved March $\quad 5, \quad 2014$ from http//www.chinadaily.com.cn/m/yunnan/cultureindustry/2014-02/08/content_17272106.htm.

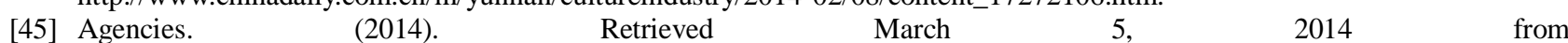
http://www.chinadaily.com.cn/business/motoring/2014-02/25/content_17304349.htm.

[46] Hou Liqiang. (2014). Retrieved March 8, 2014 from http://www.chinadaily.com.cn/china/2014-03/05/content_17325103.htm.

$\begin{array}{llllll}\text { [47] Hao } & \text { Yan } & \text { (2014). } & \text { Retrieved } & \text { March } & \text { 9, }\end{array}$ http://www.chinadaily.com.cn/business/motoring/2014-03/07/content_17329336.htm.

[48] Review\& outlook, the Wall Street Journal. (2014). Retrieved March 7, 2014 from http://online.wsj.com/news/articles/SB10001424052702304554004579422743867095108?mg=reno64-wsj\&url=http\%3A\%2F \%2Fonline.wsj.com\%2Farticle\%2FSB10001424052702304554004579422743867095108.html.

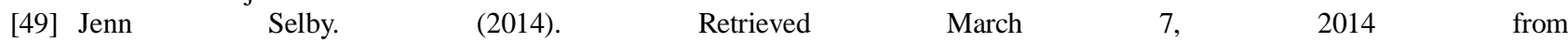
http://www.independent.co.uk/news/people/news/belle-knox-how-the-duke-university-law-student-became-one-of-the-most-se arched-for-people-on-the-internet-9174254.html.

Guineng Mei was born in Guidong County, Hunan Province, China in 1963. He received his M.A in linguistics from Hunan University, China in 1996.

$\mathrm{He}$ is currently an associate professor in Foreign Languages College, Zhejiang Gongshang University, Zhejiang, China. His interests include English linguistics, Applied linguistics, and translation skills. 